\title{
PERANCANGAN PENGAMANAN SERVER SECARA OTOMATIS MENGGUNAKAN METODE ADAM \\ (AUTOMATIC EVENT DETECTION AND ACTIVITY MONITORING)
}

\author{
Anggraini Kusumaningrum, Rolas Sianturi \\ Program Studi Teknik Informatika \\ Sekolah Tinggi Teknologi Adisutjipto Yogyakarta \\ informatika@stta.ac.id
}

\begin{abstract}
In an era like today's global, Internet-based information system security is a must to be considered, because of the public nature of the internet network and global is not safe. Basically the threat is coming from someone who wishes mempuyai gain illegal access to a computer network. Whenever there is a threat encountered on the server such as port scanning, the attacker $I P$ addresses will be captured. Next will be used method Automatic Event Detection and Activity Monitoring (ADAM) to process security. ADAM will carry out retaliatory attacks in the form of a computer virus that was sent to the attacker. For this reason when a computer network is attacked by the intruder, then ADAM server will detect this type of attack is done, then asked for help from another server to strike back. Security server by applying the method ADAM able to do the blocking of port scanning the attacker did not end there ADAM will then send the file is a virus automatically. In terms of time efficiency, the method of securing the ADAM automatically faster than if all phases of the security is done manually. ADAM test non-adaptive systems this takes 4.4 minutes, while the time taken by the ADAM system to immobilize the attacker system only 1 minute 03:59 seconds, so the method ADAM works faster. Traffic normal state ( $R X 232 B, 144 B T X)$, but when encountered in the form of port scanning attacks become 21.46Kib TX RX 25.83Kib, and after working as $R X 219 B$ ADAM TX127B, resulting in a significant reduction in traffic.
\end{abstract}

Keywords: Information Systems Security, Server Monitoring, Threat Detection.

\section{Pendahuluan}

ADAM merupakan sebuah metode pengamanan jaringan yang mampu melakukan monitoring secara real time, dan menentukan kebijakan pengamanan secara otomatis ketika ditemui sebuah serangan. ADAM akan bekerja ketika ditemui serangan berupa port scanning dari IP yang berasal dari kelompok IP whitelist. Perumusan masalah pada metode ADAM yaitu merancang dan membangun sebuah keamanan server yang mampu mendeteksi adanya sebuah aktivitas serangan, membangun sistem yang adaptif dan mampu mengatasi masalah terhadap serangan dan mampu berkomunikasi dengan server lainnya untuk memberikan sebuah serangan balasan terhadap sistem attacker secara otomatis. Sistem automatisasi hanya bekerja ketika ditemui serangan port server, komunikasi antar server hanya pada dua buah server dengan bahasa pemrograman berbasis PHP dan sistem operasi Ubuntu. 


\section{Metodologi Penelitian}

\subsection{Analisa Metode ADAM}

ADAM merupakan sebuah metode pengamanan jaringan yang mampu melakukan monitoring secara realtime, dan mendeteksi serangan port scanning terhadap server, kemudian melakukan tindakan sesuai kebijakan keamanan yang telah ditetapkan. Dalam perancangan metode ADAM dibutuhkan sistem monitoring yang mampu mendekteksi akan adanya serangan terhadap server untuk mendapatkan sebuah pemicu terjadinya automatisasi.

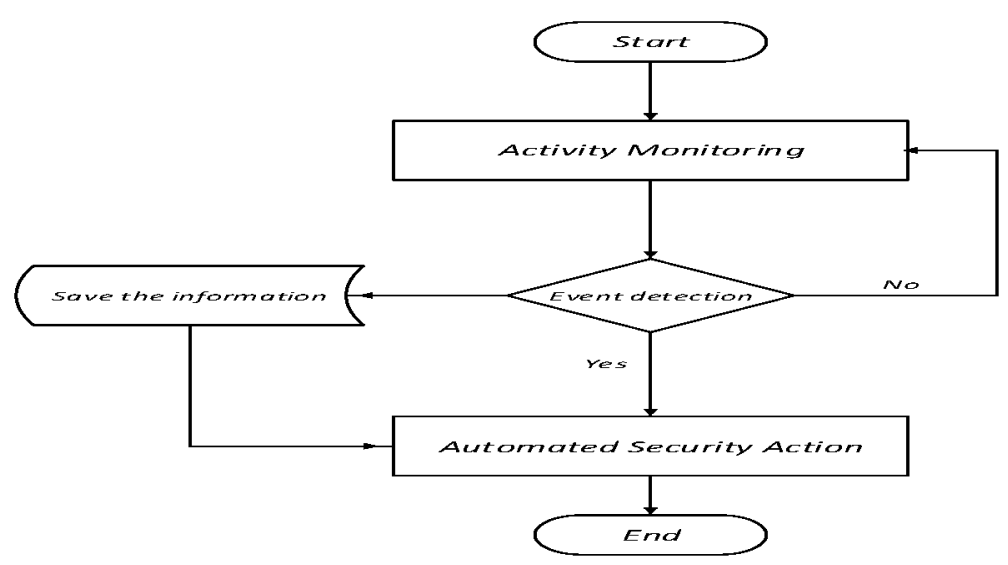

Gambar 1. Perancangan Metode ADAM

\subsection{Perancangan Sistem}

Bagan alur sistem monitoring pada server ini bekerja secara real timeuntuk memantau paketpaket data yang dilewatkan dalam jaringan komputer.

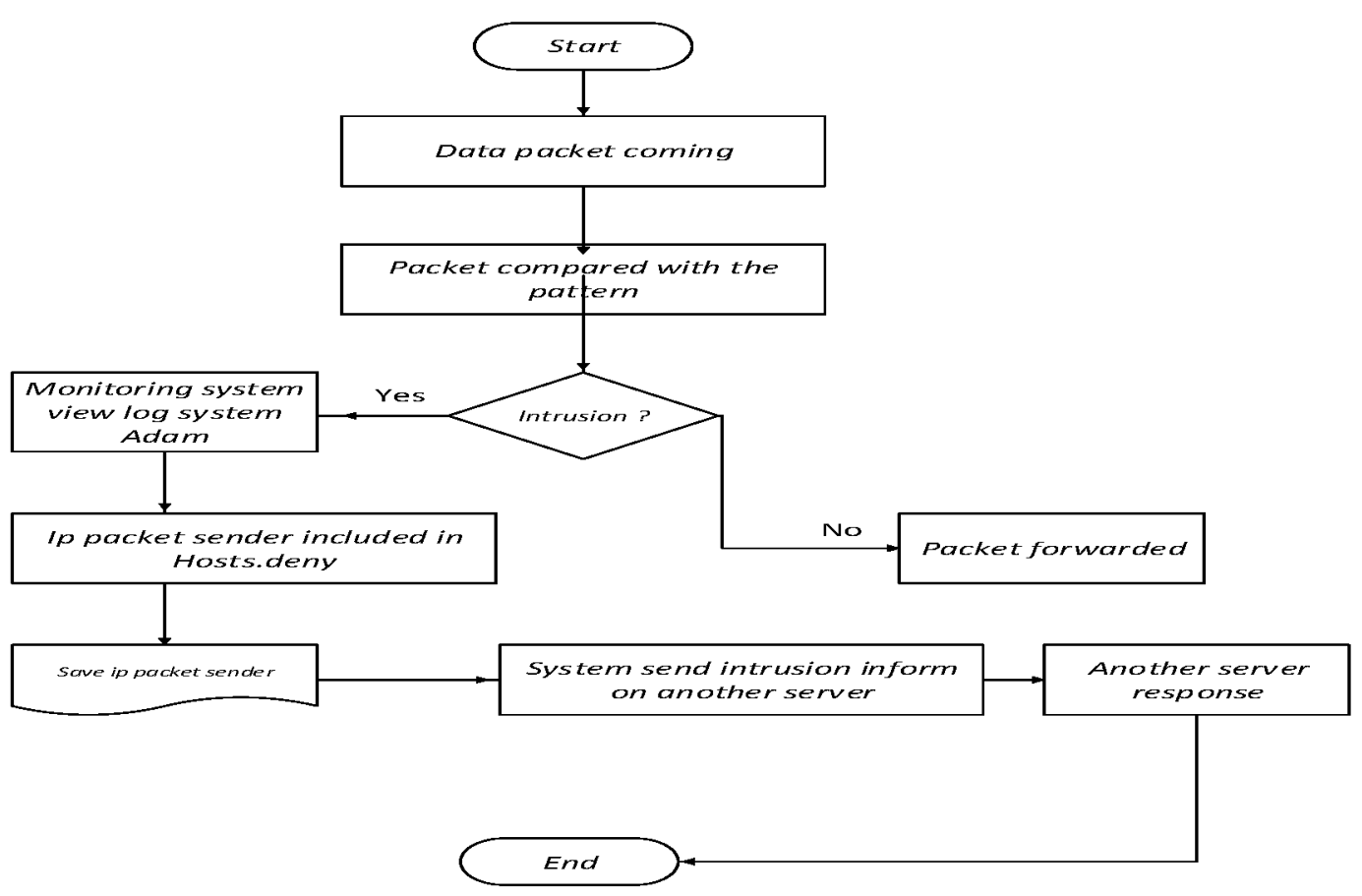

Gambar 2. Perancangan Sistem Monitoring 
Pada kebijakan keamanan yang akan diterapkan pada sistem keamanan server yaitu ketika sistem monitoring mendeteksi adanya serangan, maka server menghubungi server lain untuk menginfomasikan adanya indikasi serangan.

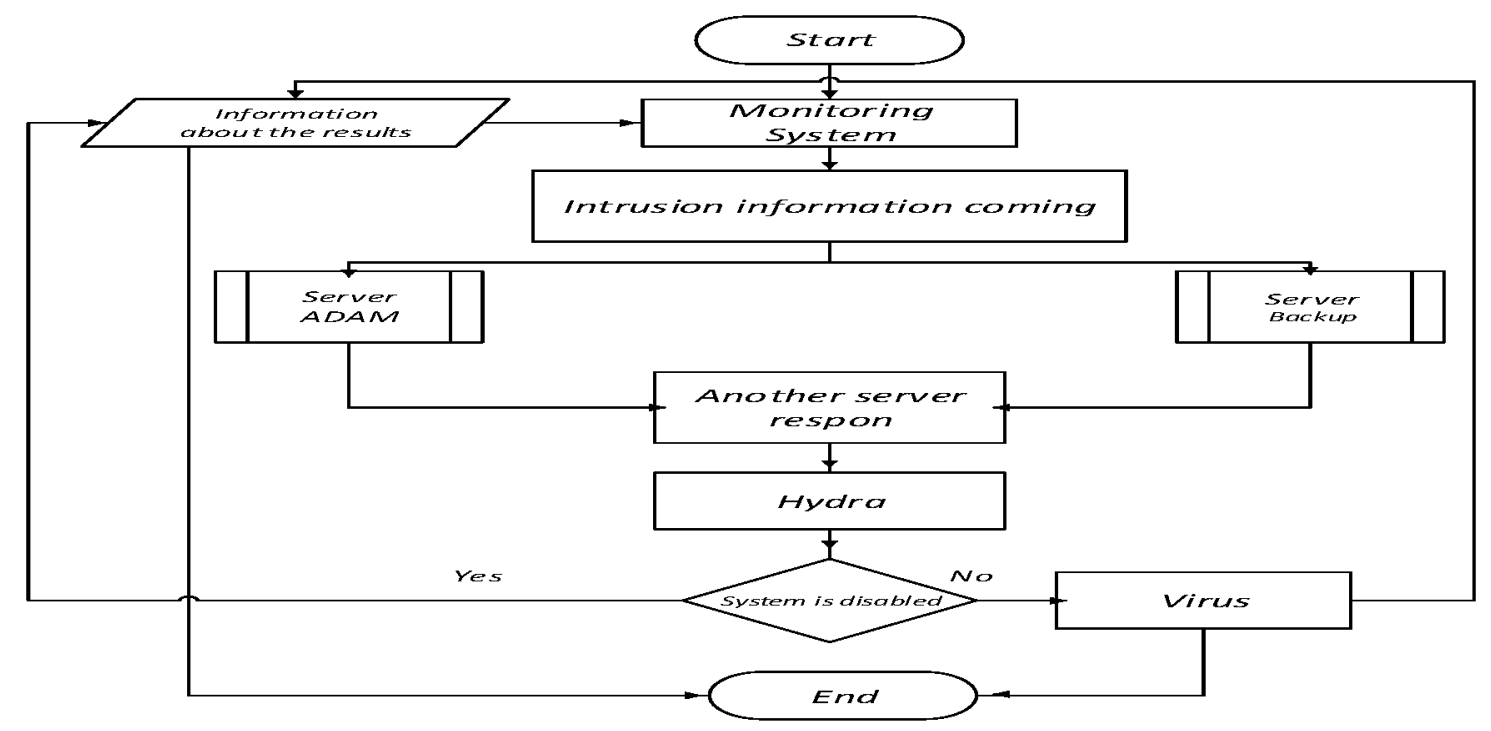

Gambar 3. Perancangan Kebijakan Keamanan

\subsection{Perancangan Uji Coba}

Pengujian sistem keamanan server dengan menerapkan metode $A D A M$ dimulai dengan melakukan intrusi terhadap server, oleh sistem monitoring akan terdeteksi adanya sebuah ancaman maka secara otomatis security policyyang diterapkan pada server akan bekerja untuk memberikan kebijakan keamanan kepada pelaku intrusi. Uji serangan yang dilakukan menggunakan Tools Zenmapuntukscanning port.Dalam mengamankan sebuah server dengan sistem keamanan yang dibangun ini seorang administrator jaringan tidak banyak melakukan intruksi untuk sistem keamanan ini karena sistem keamanan bekerja secara adaptif dan automatisasi.

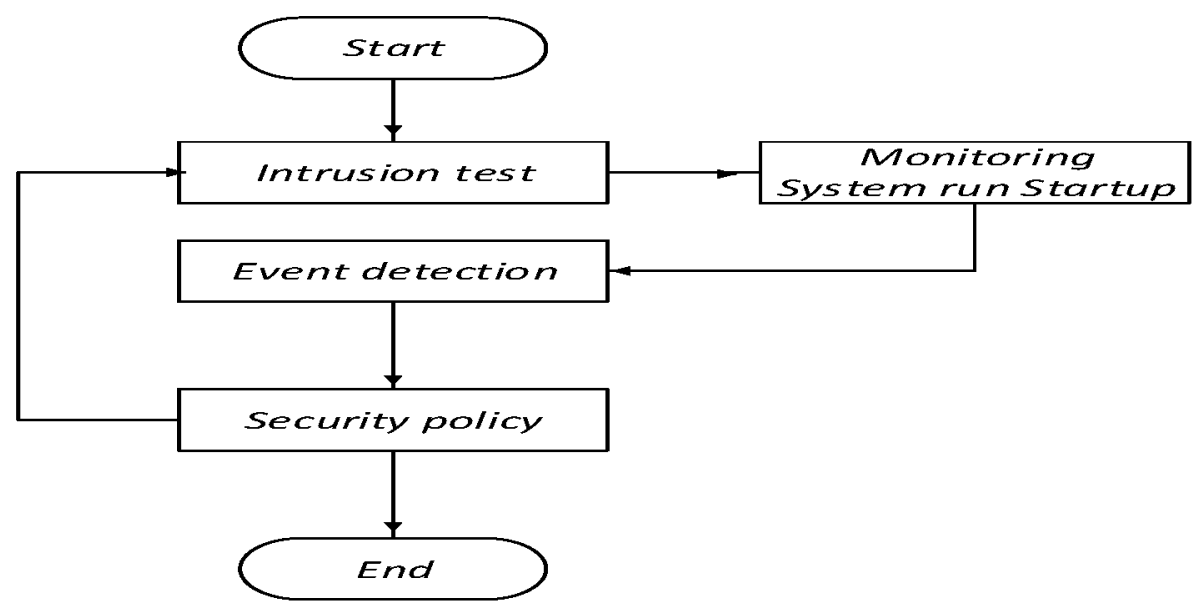

Gambar 4. Perancangan Uji Coba 


\section{Implementasi Dan Pembahasan}

Sebelum melakukan instalasi dan konfigurasi apache2 pastikan terlebih dahulu bahwa repository Ubuntu 14.04 LTS sudah diganti dengan repo local untuk mempercepat proses update package Ubuntu.

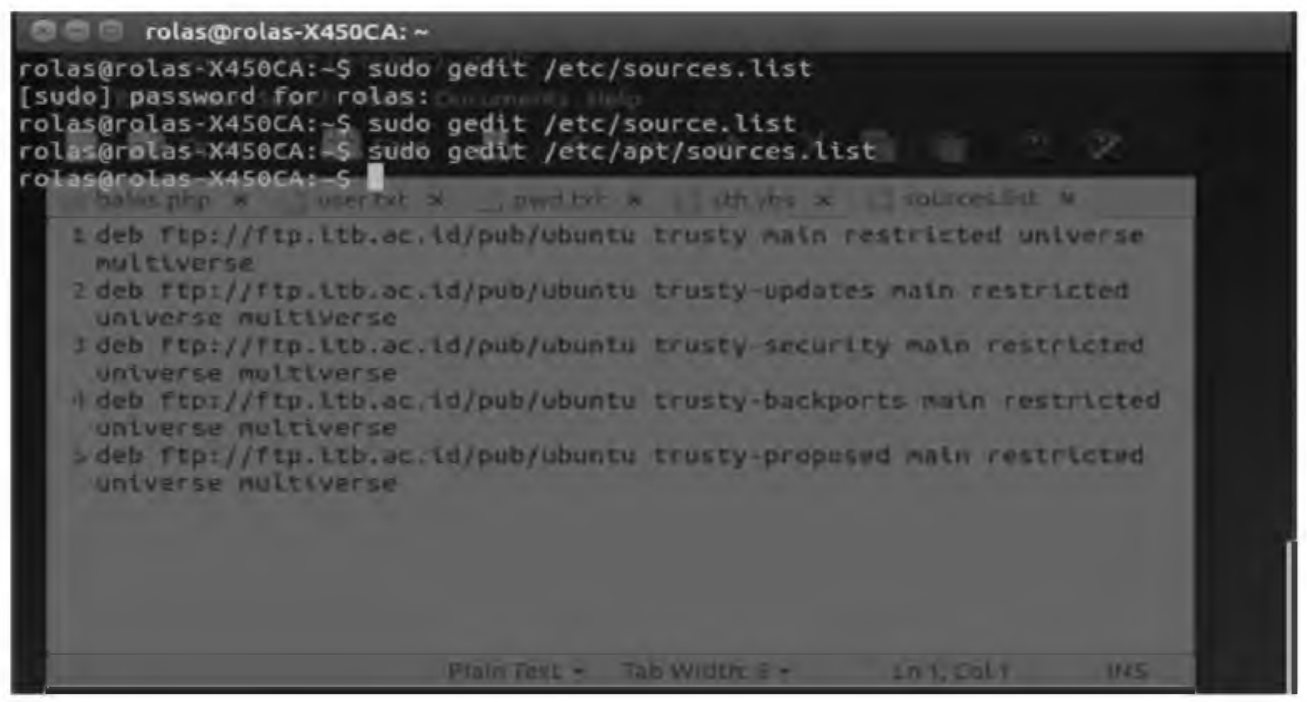

Gambar 5. Source Repository Ubuntu 14.04

Konfigurasi system pada server backup terdapat beberapa proses konfigurasi yaitu apache2, php5, ftp server, incrontab, lynx dan hydra.

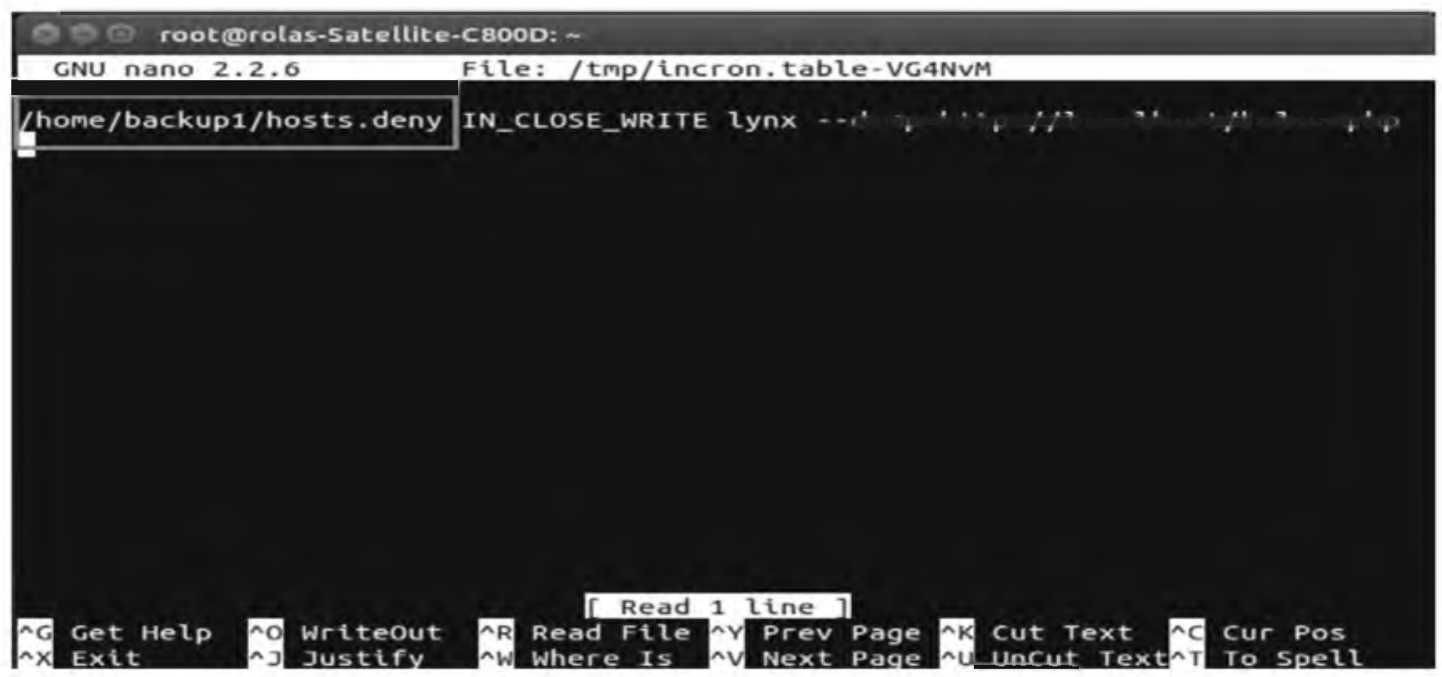

Gambar 6. Cron Jobs Server Backup

Informasi dari server ADAM diletakan pada direktori FTP server backup oleh server ADAM. Yang kemudian diambil oleh server backup untuk melakukan serangan terhadap attacker. Informasi dari server ADAM diletakan pada direktori FTP server backup oleh server ADAM. Yang kemudian diambil oleh server backup untuk melakukan serangan terhadap attacker. 


\subsection{Penjelasan Sistem ADAM}

Sistem pendeteksi serangan yang diterapkan pada sistem ADAM ini adalah kemampuan server dalam menangkap informasi attacker yang melakukan aktivitas hacking.

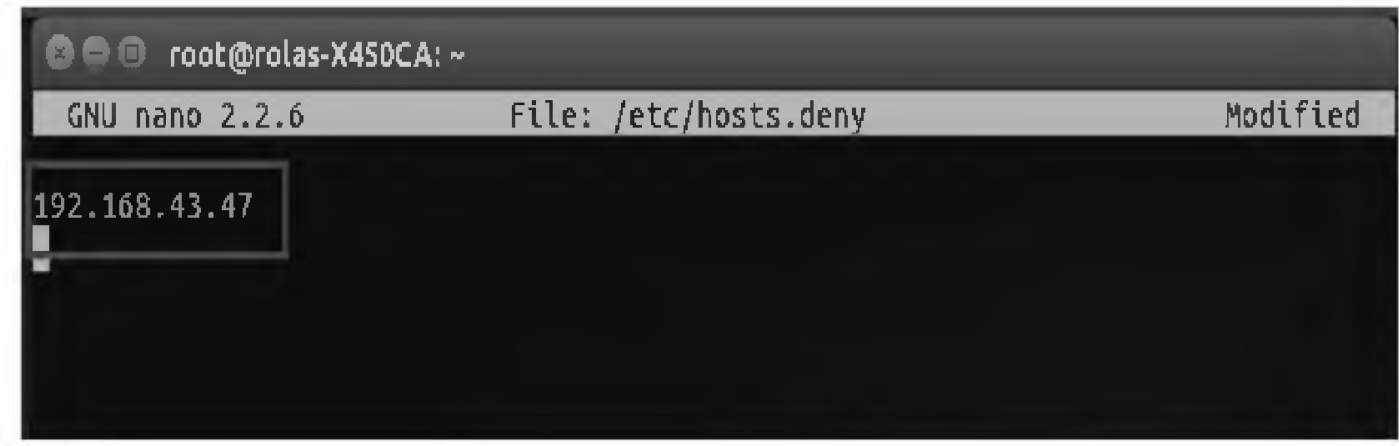

Gambar 7. Hasil Deteksi Serangan

Sistem komunikasi antar server, yakni server ADAM dan server backup bertujuan untuk berbagi informasi tentang attacker, yang kemudian melakukan serangan balasan secara bersamasama.

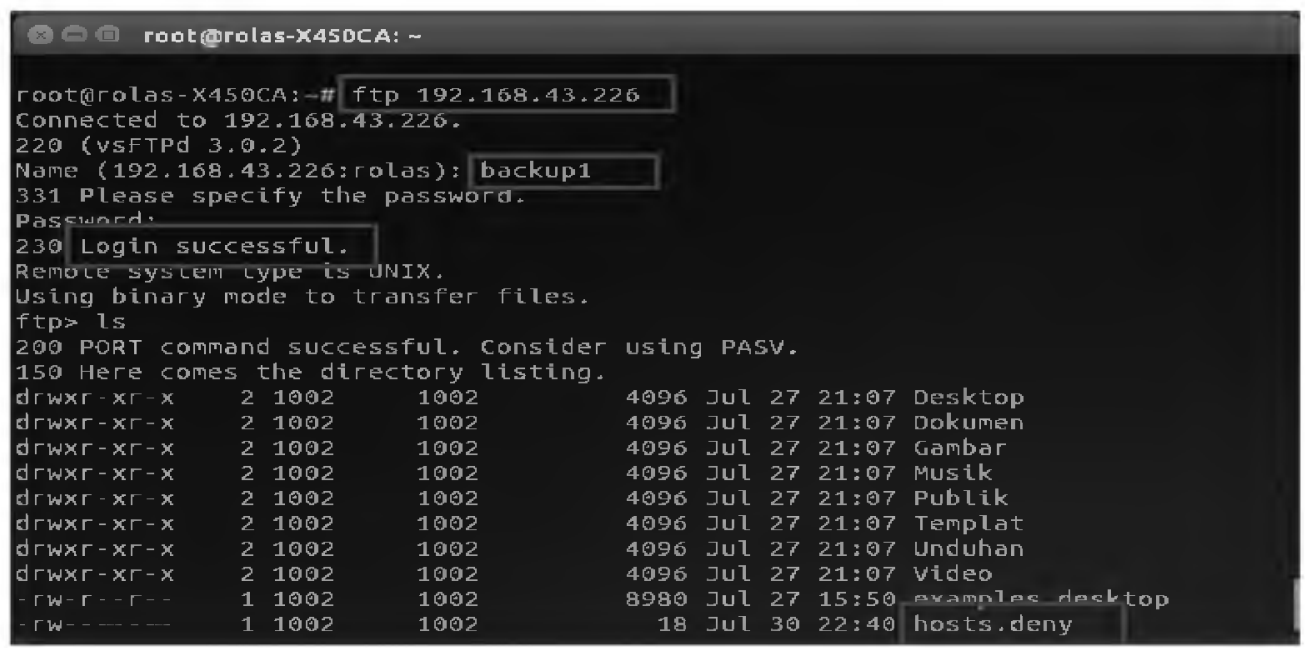

Gambar 8. Hasil Komunikasi Antar Server

Sistem serangan balasan yang diterapkan pada sistem ADAM dimaksudkan untuk memberikan efek jera terhadap attacker.

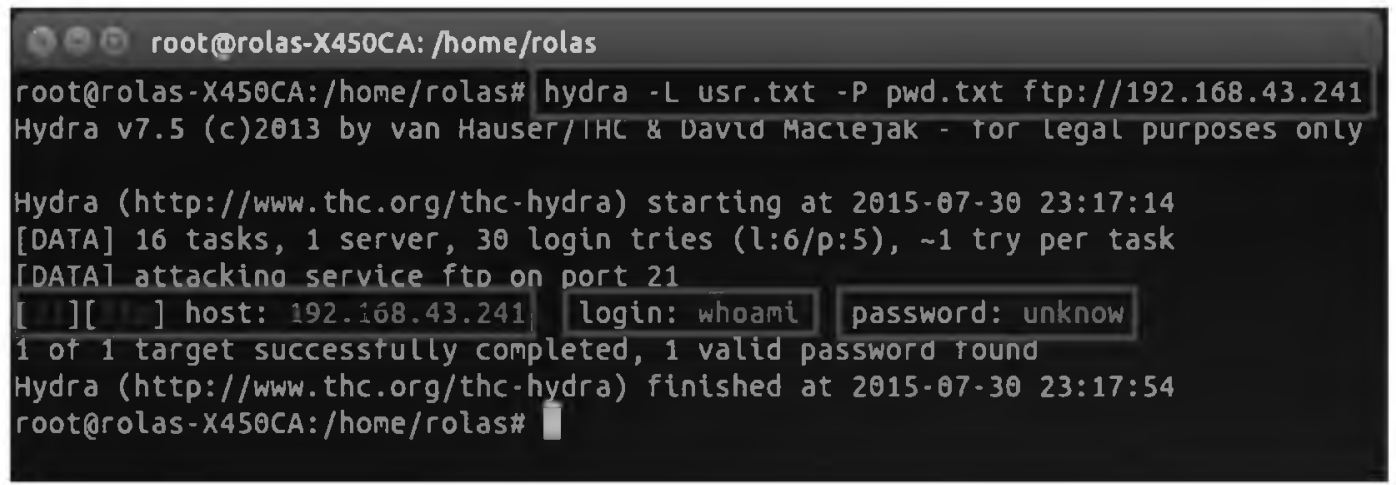

Gambar 9. Hasil Serangan Balasan 


\subsection{Uji Deteksi Serangan}

Uji deteksi serangan pada server ADAM menggunakan ports entry yang bertugas untuk mendeteksi akan adanya serangan pada port server dan menangkap IP attacker serta menyimpannya ke dalam file hosts.deny.

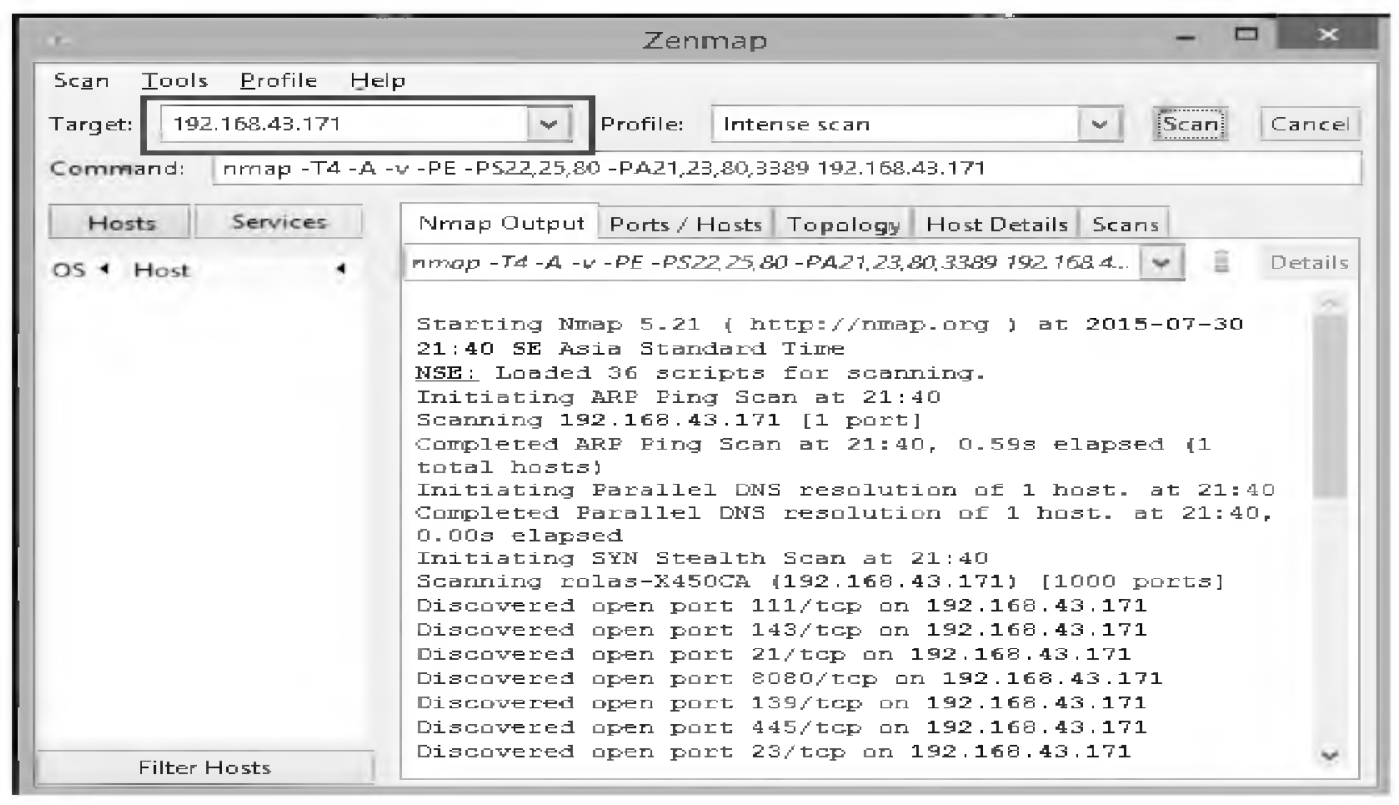

Gambar 10. Scanning port dengan nmap

Uji otomatisasi sistem ADAM adalah pengujian system secara keseluruhan dengan metode Automate Event Detection and Activity Minitoring.

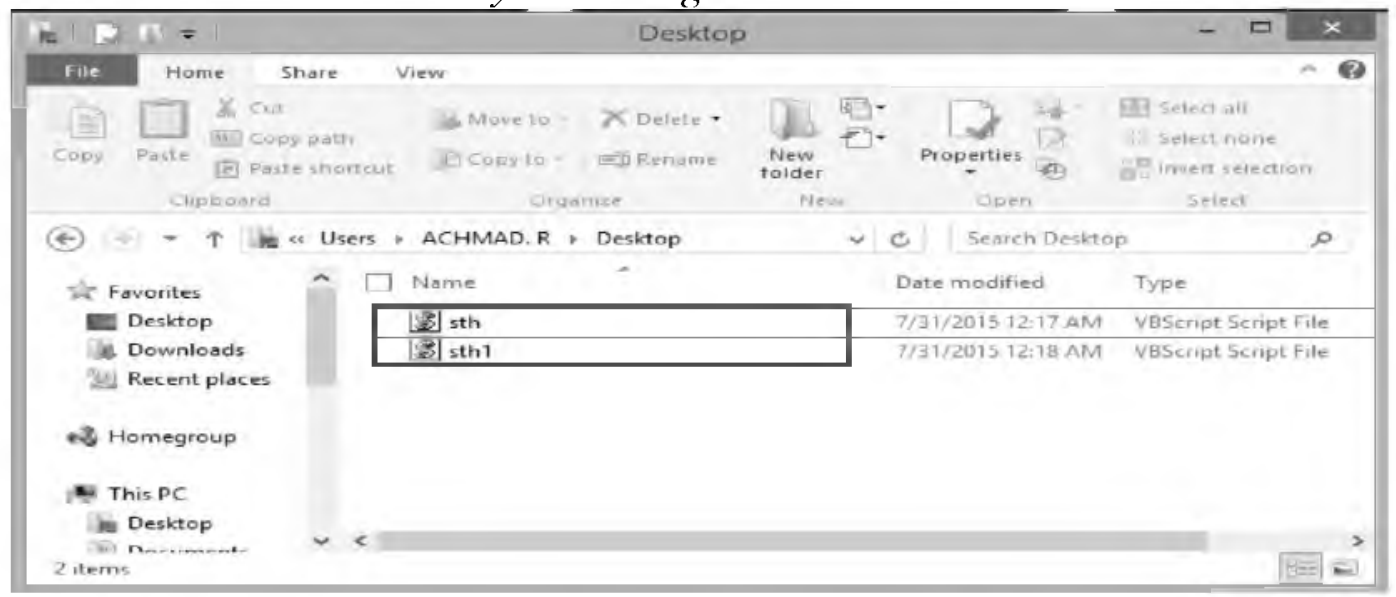

Gambar 11. File Virus Uji Otomatis

\section{Penutup}

\subsection{Kesimpulan}

1. Sistem otomatisasi ADAM mampu bekerja dalam menangani adanya jenis serangan terhadap port server, dan mampu menangkap IP address yang melakukan jenis serangan tersebut.

2. Sistem ADAM yang diterapkan pada server mampu berkomunikasi dengan server lainnya untuk berbagi informasi tentang attacker melalui FTP server. 
3. Sistem ADAM mampu melakukan serangan balasan secara bersama-sama dengan server backup untuk melumpuhkan system attacker dengan menyisipkan virus ke dalam system attacker tersebut.

4. Sistem otomatisasi ADAM bekerja lebih cepat dibandingkan dengan sistem keamanan yang bekerja dengan cara manual.

5. Trafik jaringan setelah ADAM bekerja ketika ditemui serangan jenis scanning port akan lebih rendah dibanding sebelum ADAM bekerja.

\subsection{Saran}

1. Untuk pengembangan selanjutnya, system pendeteksi serangan lebih diperluas lagi agar dapat mendeteksi berbagai jenis serangan terhadap server.

2. Server backup yang bertugas membantu server ADAM dalam melakukan serangan balasan ditambahkan lebih dari satu server.

\section{Daftar Pustaka}

Eichel,Zee., Baster, James., Rizqi, Habibi., 2012. Attacking Site With Backtrack. Indonesian Backtrack Team.

Nikodemus, 2012. Network Hacking dengan Linux Backtrack. Penerbit : Andi Yogyakarta danWahana Komputer.

Rahman, Rizal. 2013. MahirAdministrasi Server dan Router dengan Linux Ubuntu Server 12.04 LTS.Bekasi, Creative Commons Attribution-ShareAlike 3.0 Unported License (CC by SA).

http:/blog.pusheax.com/2014/01/dictionary-and-brute-force-attack-using.html. Diakses pada 10 Juli 2015, 02:01:17 AM.

http:/blog.pusheax.com/2014/12/metasploit-port-scanning.html. Diakses pada 10 Juli 2015, 02:35:23 AM.

https:/www.howtoforge.com/triggering-commands-on-file-or-directory-changes-with-incron.

Diakses pada 14 Juli 2015, 2:04:13 PM.

http:/www.w3schools.com/php/func filesystem fgets.asp. Diakases pada 14 Juli 2015, 2:03:09 PM.

http:/www.ubuntugeek.com/bandwidth-monitoring-tools-for-ubuntu-users.html. Diakses pada 01 Agustus 2015, 20:18 WIB.

https:/id.scribd.com/doc/171582542/Gilang-Instalasi-Konfigurasi-Portsentrv. Diakses pada 2 Agustus 2015, 2:11:24 AM.

http:/www.asus87.com/2011/05/aplikasi-ftp-client-di-linux-ubuntu/. Diakses pada 02 Agustus 2015, 02:33 WIB. 
Anggraini Kusumaningrum, Rolas Sianturi. 